\title{
Hubungan antara Kepuasan Pernikahan dengan Kecemasan terhadap Menopause pada Individu yang Berada dalam Tahap Usia Menjelang Menopause
}

\author{
Puti Amalina \\ Melok Roro Kinanthi \\ E-mail : putiamalina@yahoo.com \\ Fakultas Psikologi Universitas YARSI Jakarta
}

\begin{abstract}
ABSTRAK
Meski menopause merupakan siklus alami, namun ternyata tidak semua perempuan dapat menerima hal ini dengan baik. Terdapat perempuan yang merasa cemas terhadap menopause. Intensitas kecemasan yang sedang, bahkan tinggi dapat menyebabkan depresi dan mengurangi kualitas hidup perempuan. Kecemasan, termasuk kecemasan terhadap menopause, jika tidak diatasi dan tidak dikendalikan dapat menimbulkan gangguan psikosomatis hingga depresi berat yang dapat menurunkan kualitas hidup perempuan. Untuk mengantisipasi terjadi hal tersebut, perlu dilakukan upaya pengembangan intervensi yang dapat memimalisir, mengantisipasi, dan menghilangkan kecemasan. Salah satu caranya adalah dengan mengidentifikasikan faktor-faktor apa saja yang berkorelasi dengan kecemasan terhadap menopause.

Penelitian ini bertujuan mengetahui hubungan antara kepuasan pernikahan dengan kecemasan terhadap menopause pada individu yang berada dalam tahap usia menjelang menopause. Penelitian ini melibatkan 100 orang perempuan yang masih menikah dan memilikisuami, serta berada dalam tahap usia menjelang menopause (40 - 48 tahun). Pemilihan partisipan dilakukan dengan teknik sampling yakni accidental sampling. Instrumen penelitian yang digunakan untuk mengumpulkan data adalah ENRICH Marital Satisfaction (Fowers \& Olson, 1993) dan alat ukur kecemasan terhadap menopause yang dikembangkan sendiri peneliti. Uji korelasi Pearson Product Moments pada variable kepuasan pernikahan dengan kecemasan terhadap menopause menghasilkan hubungan negatif yang signifikan diantara keduanya $(r=$ $-0,774 ; p<0,05)$. Hal ini memiliki arti semakin tinggi kepuasan pernikahan, maka semakin rendah tingkat kecemasan terhadap menopause yang dirasakan partisipan. Sebaliknya, semakin rendah kepuasan pernikahan, maka semakin tinggi tingkat kecemasan terhadap menopause. Dengan demikian, kecemasan terhadap menopause dapat dikendalikan melalui pernikahan atau interaksi antara suami dan istri yang memuaskan. Peningkatan kualitas pernikahan menjadi sesuatu yang penting bagi pasutri pada usia paruh baya.
\end{abstract}

Kata Kunci: Menopause, Kepuasan Pernikahan, Kecemasan 


\section{PENDAHULUAN}

Jumlah perempuan yang menghadapi menopause meningkat dari tahun ke tahun. Menurut data statistik, diperkirakan pada tahun 2020 terdapat sekitar 30,3 juta perempuan yang hidup dalam usia menopause (Depkes RI, 2005). Data BPS (dalam Proyeksi Penduduk, 2008) menunjukkan terdapat 5.320 .000 wanita Indonesia memasuki usia menopause per tahunnya. Terjadi perubahan yang signifikan pada aspek fisik maupun psikologis perempuan pada saat menopause, yakni munculnya keringat berlebihan, rasa panas di wajah, gejolak emosi berlebihan, dan perasaan tidak berguna. Selain itu, dapat juga terjadi gangguan dalam kegiatan seksual pasutri (Christiani, Retnowati, \& Purnamaningsih, 2000). Berbagai perubahan tersebut dapat menimbulkan perasaan tidak nyaman pada perempuan. Misalnya, adanya reaksi penolakan perempuan terhadap berkurangnya kualitas keperempuanan, yakni dalam hal kecantikan dan vitalitas (Kartono, dalam Christiani, Retnowati, \& Purnamaningsih, 2000).

Meski menopause merupakan siklus alami, namun ternyata tidak semua perempuan dapat menerima hal ini dengan baik. Data mengenai hal ini tercermin dalam sejumlah hasil penelitian. Sebagai contoh, hasil penelitian Hanafiah (1999) menunjukkan sebanyak $75 \%$ perempuan yang akan menghadapi masa menopause menganggap menopause sebagai sebuah masalah atau gangguan. Adapun hasil penelitian Muntiah dan Ni'amah (2013) menunjukkan terdapat 7 dari 10 orang perempuan berusia 45-50 tahun yang merasa cemas terhadap datangnya masa menopause. Kemudian, hasil penelitian O'Hara (dalam Hidayah, Hadi \& Atik, 2016) menunjukkan terdapat $69,8 \%$ perempuan pada usia menjelang menopause yang merasa stres dan tidak siap menghadapi menopause. Selain itu, adanya perempuan yang mengalami kegelisahan dan kekhawatiran akan memasuki masa menopause juga dapat ditemukan dalam hasil penelitian Rostiana dan Kurniati (2009). Di Jakarta dikemukakan bahwa perempuan mempunyai lima gejala utama yang dialami dalam menghadapi masa klimakterik seperti, nyeri otot atau sendi $(77,7 \%)$, rasa letih dan hilang energi $(68,7 \%)$, kehilangan nafsu seksual $(61,3 \%)$, kerutan di kulit (60\%), sulit konsentrasi dan hot flushes $(29,5 \%)$ (Muharam, 2007) dan bagi sebagian besar perempuan di Jakarta, menopause dipandang sebagai hal negatif dan menopause juga dipandang sebagai hal yang menakutkan (Prasetya, Firmiana \& Imawati, 2012).

Kecemasan terhadap menopause merupakan hal yang wajar terjadi jika masih dalam intesitas ringan. Meski demikian, intensitas kecemasan yang sedang, bahkan tinggi dapat menyebabkan depresi dan mengurangi kualitas hidup perempuan (Aprilia \& Puspitasari, 2007). Kecemasan, termasuk kecemasan terhadap menopause, jika tidak diatasi dan tidak dikendalikan dapat menimbulkan gangguan psikosomatis hingga depresi berat yang dapat menurunkan kualitas hidup perempuan (Lestary, dalam Handayani, 2015). Untuk mengantisipasi terjadi hal tersebut, perlu dilakukan upaya pengembangan intervensi yang dapat memimalisir, mengantisipasi, dan menghilangkan kecemasan. Salah satu caranya adalah dengan mengidentifikasikan faktor-faktor apa saja yang berkorelasi dengan kecemasan terhadap menopause. Dengan mengetahui faktor-faktor tersebut, dapat dilakukan cara yang tepat untuk 
mengelola kecemasan dalam menghadapi menopause.

Terdapat sejumlah faktor yang berkorelasi dengan kecemasan terhadap menopause. Menurut Rostiana dan Kurniati (2009), kecemasan terhadap menopause muncul karena individu tidak mendapatkan informasi yang benar tentang menopause dan adanya kekhawatiran menopause akan mempengaruhi hubungannya dengan suami dan lingkungan. Para perempuan juga mengaitkan menopause dengan timbulnya penyakit kanker atau penyakit-penyakit yang sering muncul pada saat memasuki usia tua. Faktor lainnya yang berkaitan dengan kecemasan terhadap menopause adalah sikap yang memandang suatu permasalahan dari sisi negatif, kurangnya dukungan keluarga, tingkat pendidikan, status pekerjaan, dan kondisi ekonomi (Aprillia \& Puspitasari, 2007); kesalahan proses kognisi yang membuat partisipan takut tua dan tidak cantik lagi (Rostiana \& Kurniati, 2007); dan dukungan suami (Muntiah \& Ni'amah, 2013).

Masih sedikit penelitian yang mempertimbangkan relasi individu dengan keluarga terdekatnya sebagai faktor yang mungkin berkorelasi dengan kecemasan dalam menghadapi menopause. Padahal keluarga merupakan sumber dukungan terdekat dan utama bagi individu untuk dapat mengelola atau mengatasi kecemasannya. Peneliti mempertimbangkan relasi pernikahan yang memuaskan sebagai faktor yang memiliki keterkaitan dengan kecemasan menghadapi menopause. Chapel dan Leigh (dalam Sumpani, 2008) menyebutkan kepuasan pernikahan sebagai evaluasi subjektif terhadap kualitas pernikahan secara keseluruhan. Apabila seseorang merasa puas terhadap pernikahan yang telah dijalani, maka dia beranggapan bahwa harapan, keinginan dan tujuan yang dicapai pada saat menikah telah terpenuhi, baik sebagian ataupun seluruhnya. Individu yang mengalami kepuasan dalam pernikahannya merasa hidupnya berarti dan lebih lengkap dibandingkan dengan sebelumnya.

Pertimbangan untuk meneliti keterkaitan antara kepuasan pernikahan dan kecemasan terhadap menopause didasari oleh sejumlah teori dan hasil penelitian mengenai hal tersebut. Kepuasan pernikahan memiliki korelasi dengan emosi negatif dan juga kesehatan mental pada perempuan. Sebagai contoh, kepuasan pernikahan merupakan faktor yang dapat memprediksikan terjadinya kecemasan pada perempuan selama kehamilan (Salehi \& Shahhosseini, 2017). Sebaliknya, perempuan dengan tingkat kepuasan pernikahan yang rendah, cenderung mengalami kecemasan yang lebih tinggi di masa kehamilan (Rabanazari dkk, dalam Salehi \& Shahhosseini, 2017). Kepuasan pernikahan memiliki peran yang penting bagi kesehatan mental perempuan. Perempuan yang memiliki kesehatan mental yang baik akan dapat mengendalikan kecemasan dan depresinya (Abedi dkk, dalam Salehi \& Shahhosseini, 2017). Contoh lainnya, disfungsi pernikahan berkorelasi dengan depresi dan kesehatan yang buruk (Frech \& Williams, dalam Acevedo, Aron, Fisher, \& Brown, 2012; Kiecolt- Glaser dkk, dalam Acevedo, Aron, Fisher, \& Brown, 2012). Kaitan antara kepuasan pernikahan dengan kecemasan dapat dijelaskan melalui hasil penelitian Acevedo dkk (2012) yakni terdapat korelasi antara tingkat kepuasan pernikahan dengan daerah di otak yang terkait dengan regulasi afek dan stress. Adanya regulasi afek ini memungkinkan individu untuk melindungi dirinya dari kecemasan, stres, dan depresi. 
Hasil penelitian Khan (2013) menunjukkan bahwa kepuasan pernikahan dapat memberikan kesehatan psikologis dan mental pada individu, sehingga individu akan dapat meregulasi kecemasan dalam menghadapi menopause atau bahkan meredamnya sehingga tidak muncul sama sekali. Adapun hasil penelitian Dehle \& Weiss (1998) menunjukkan bahwa kualitas pernikahan yang rendah dapat menurunkan kesehatan psikologis, meningkatkan stres psikologis serta berkorelasi dengan meningkatnya depresi terutama pada perempuan. Levenson dkk (1994) juga mengatakan kepuasan pernikahan dapat berpengaruh pada cara pandangnya terhadap diri, lingkungan, maupun masa depannya. Kepuasan pernikahan yang baik dapat membuat cara pandang yang positif pada perempuan yang akan menghadapi masa menopause.

Penelitian terkait kecemasan menopause yang ada sebelumnya lebih banyak meneliti tingkat kecemasan yang dialami perempuan pada saat menopause (seperti Christiani, Retnowati, \& Purnamaningsih, 2000; Handayani, 2015; Hidayah, Hadi, \& Atik, 2016) dan bukan tingkat kecemasan terhadap menopause pada perempuan dengan usia menjelang menopause yang berumur 40-48 tahun seperti fokus penelitian ini. Berbagai hasil penelitian tersebut menunjukkan bahwa tingkat kecemasan pada saat menopause berkorelasi dengan persepsi dan pengetahuan tentang menopause (Christiani, Retnowati, \& Purnamaningsih, 2000; Aprilia \& Puspitasari, 2007), dan perubahan fisik (Handayani, 2015). Adapun penelitian mengenai tingkat kecemasan terhadap menopause telah dilakukan oleh Rostiana dan Kurniati (2007) serta Aprilia dan Puspitasari (2007). Penelitian Rostiana dan Kurniati (2007) dilakukan dengan pendekatan kualitatif dan hanya melibatkan seorang perempuan yang mulai mengalami gejala menopause. Sementara itu, hasil penelitian Aprilia \& Puspitasari (2007) menunjukkan kecemasan terhadap menopause dipengaruhi oleh sikap terhadap menopause, dukungan keluarga, status pekerjaan, dan kondisi ekonomi. Akan tetapi, penelitian tersebut tidak memiliki batasan partisipan secara tegas. Penelitian tersebut mengikutsertakan perempuan yang berada dalam tahap pra menopause dan menopause, sementara dalam penelitian ini peneliti hanya berfokus pada perempuan menghadapi menopause saja. Untuk mengisi kekosongan kajian yang ada dan juga mempertimbangkan manfaat praktis yang diperoleh, peneliti akan melakukan penelitian mengenai hubungan kepuasan pernikahan dengan kecemasan terhadap menopause pada perempuan dengan usia menjelang menopause.

\section{METODE}

Penelitian ini menggunakan pendekatan kuantitatif dengan desain asosiatif. Terdapat dua variabel yang diteliti dalam penelitian ini, yakni kepuasan pernikahan dan kecemasan terhadap menopause. Dalam penelitian ini, kepuasan pernikahan didefinisikan sebagai evaluasi individu terkait sejauhmana terpenuhinya sepuluh aspek dalam pernikahan, yaitu aspek kepribadian, komunikasi, aktivitas di waktu luang, orientasi religius, resolusi konflik, manajemen keuangan, hubungan seksual, keluarga dan teman, anak dan pengasuhan, serta peran yang setara dengan pasangan (Fowers \& Olson, 1989). Sementara itu, definisi kecemasan terhadap menopause dalam penelitian ini adalah suatu perasaan takut yang menyebar, samar, dan tidak menyenangkan terkait datangnya masa menopause yang muncul 
dalam bentuk gejala fisik, kognitif, afektif, dan perilaku.

Penelitian ini melibatkan 100 perempuan yang berada dalam tahap usia menjelang menopause, yakni 40-48 tahun, masih menikah dan memiliki suami, serta berdomisili di Jakarta. Instrumen penelitian yang digunakan dalam penelitian ini berupa skala lapor diri (self report). Untuk mengukur tingkat kepuasan pernikahan dalam penelitian ini, peneliti menggunakan ENRICH (Evaluating \& Nurturing Relationship Issues, Communication, Happiness) Marital Satisfaction Scale (atau disingkat EMS) yang dikembangkan oleh Fower dan Olson (1993). Sementara itu, terkait untuk mengukur tingkat kecemasan terhadap menopause peneliti mengembangkan instrument ukur sendiri, dimana dimensi dan indikator nya disusun berdasarkan teori Sarason dan Sarason (2004). Uji reliabilitas terhadap kedua instrument ukur tersebut dilakukan dengan menggunakan teknik Cronbach's Alpha. Koefisien reliabilitas untuk EMS adalah $\alpha=0,919$ dan untuk instrument kecemasan terhadap menopause yang dikembangkan peneliti menghasilkan koefisien reliabilitas 0,902. Adapun dari hasil uji validitas dengan melihat nilai corrected item total correlation, peneliti mendapatkan koefisien validitas di atas 0,02 untuk seluruh butir aitem pada EMS maupun instrumen Kecemasan terhadap Menopause. Terhadap data yang telah diperoleh, peneliti kemudian melakukan analisis statistik deskriptif, uji normalitas dengan menggunakan teknik Kolmogorov-Smirnov, dan uji hipotesis dengan korelasi Pearson's Product Moment.

\section{HASIL}

Gambaran Umum Partisipan
Sebagian besar partisipan ini berusia $40-45$ tahun $(69 \%)$, berpendidikan tinggi (Diploma, S1, S2 dan S3) (82\%), bersuku Jawa (42\%), dan beragama Islam (92\%). Terkait dengan relasi pernikahan, mayoritas partisipan memiliki usia pernikahan 16-20 tahun (54\%) dengan tiga orang anak (41\%). Partisipan penelitian ini didominasi oleh mereka yang berstatus sebagai ibu rumah tangga (35\%) dengan pengeluaran per bulan sekitar Rp5.000.001-Rp10.000.000 (53\%).

Sebanyak $80 \%$ partisipan, mengalami menstruasi untuk pertama kali pada usia 11-15 tahun (80\%). Adapun gejala fisik pada saat menghadapi menopause yang dirasakan saat ini ialah vagina terasa kering (33\%), menstruasi tidak teratur sebesar (45\%), pengontrolan urin tidak baik (24\%), merasakan semburan/perasaan panas pada bagian kepala, leher, dan dada yang muncul secara tiba-tiba dan disertai keringat yang banyak (hot flushes) (14\%), dan berat badan bertambah sebesar (57\%). Sedangkan gejala psikologi pada saat menghadapi menopause yang dirasakan yaitu mudah lelah sebesar (77\%), mudah marah sebesar (61\%), penurunan dorongan/gairah seksual (18\%), tidak percaya diri (14\%), mudah lupa (30\%), susah tidur (22\%), dan suasana hati yang berubah-ubah (33\%).

Gambaran Kecemasan terhadap Menopause pada Perempuan dengan Usia Menjelang Menopause

Pada partisipan penelitian ini, mayoritas (73\%) memiliki tingkat kecemasan terhadap menopause yang tergolong sedang. Adapun sisanya, yakni $16,0 \%$ memiliki tingkat kecemasan menghadapi menopause yang tergolong tinggi dan $11.0 \%$ mempunyai tingkat 
kecemasan menghadapi menopause yang rendah.

Tabel 1.

Gambaran Kecemasan terhadap Menopause pada Perempuan Menjelang Menopause

\section{N Frequency Percent}

\begin{tabular}{lccc}
\hline $\begin{array}{l}\text { Tinggi } \\
(X \geq 57)\end{array}$ & 100 & 16.00 & 16.00 \\
$\begin{array}{l}\text { Sedang } \\
(39 \leq X<57)\end{array}$ & 100 & 73.00 & 73.00 \\
$\begin{array}{l}\text { Rendah } \\
(X<39)\end{array}$ & 100 & 11.00 & 11.00 \\
\hline
\end{tabular}

Hasil Uji Normalitas

Berdasarkan hasil uji normalitas dengan menggunakan teknik KolmogorovSmirnov, data penelitian ini berdistribusi normal dengan nilai signifikansi sebesar $0,153(p>0,05)$ untuk variabel kepuasan pernikahan. Adapun untuk variabel kecemasan terhadap menopause diperoleh nilai signifikansi sebesar $0,151(p>0,05)$. Mengingat data dalam penelitian ini berdistribusi normal, maka untuk menguji hipotesis, dapat digunakan statistik parametrik dengan teknik korelasi Pearson Product Moment dengan taraf kesalahan 0,05 atau $p<0,05$ (Sugiyono, 2010).

\section{Hasil Uji}

Uji korelasi variabel kepuasan pernikahan dengan kecemasan terhadap menopause menghasilkan hubungan negatif yang signifikan diantara keduanya $(r=-0,774 ; p<0,05)$. Hal ini memiliki arti semakin tinggi kepuasan pernikahan, maka semakin rendah tingkat kecemasan terhadap menopause yang dirasakan partisipan. Sebaliknya, semakin rendah kepuasan pernikahan, maka semakin tinggi tingkat kecemasan terhadap menopause. Dengan demikian, hipotesis penelitian ini diterima.

Peneliti melakukan analisis tambahan dengan menggunakan teknik One Way Annova Test untuk melihat perbedaan tingkat kecemasan terhadap menopause antara kelompok-kelompok partisipan penelitian berdasarkan faktor-faktor demografi. Hasil analisis menunjukkan terdapat perbedaan tingkat kecemasan terhadap menopause yang signifikan ditinjau dari pekerjaan $(\mathrm{F}=3,038 ; \mathrm{p}<0,05)$, dimana rata-rata tingkat kecemasan terhadap menopause dengan skor tertinggi dialami partisipan yang berprofesi sebagai dosen. Sementara itu, tidak terdapat perbedaan yang signifikan ditinjau dari data demografi lainnya.

\section{DISKUSI}

Penelitian ini bertujuan untuk mengetahui hubungan antara kepuasan pernikahan dengan kecemasan terhadap menopause pada individu yang berada dalam tahap usia menjelang menopause. Hasil penelitian ini menunjukkan terdapat hubungan negatif yang signifikan antara kepuasan pernikahan dengan tingkat kecemasan terhadap menopause. Dengan demikian, semakin tinggi kepuasan pernikahan, maka semakin rendah tingkat kecemasan terhadap menopause yang dirasakan partisipan. Sebaliknya, semakin rendah kepuasan pernikahan, maka semakin tinggi tingkat kecemasan terhadap menopause. Hasil penelitian ini memperkuat hasil penelitian terdahulu mengenai adanya korelasi kondisi pernikahan dengan kesehatan mental pada perempuan (Salehi \& Shahhosseini, 2017; 
Fieder \& Krupius; Frech \& Williams, dalam Acevedo, Aron, Fisher, \& Brown, 2012; Kiecolt- Glaser dkk, dalam Acevedo, Aron, Fisher, \& Brown, 2012 Acevedo, Aron, Fisher, \& Brown, 2012). Dengan kesehatan mental yang baik, individu dapat mengendalikan kecemasannya (Abedi dkk, dalam Salehi \& Shahhosseini, 2017), termasuk dalam hal ini kecemasan terhadap menopause. Selain itu, tingkat kepuasan pernikahan ternyata berkorelasi dengan daerah di otak yang terkait dengan regulasi afek dan stres (Acevedo dkk, 2012). Dengan meregulasi afek dan stres, individu dapat mengelola atau meminimalisir rasa cemas, stres, dan depresi. Adapun Gove (dalam Goldsmith, 1988) mengemukakan bahwa kepuasan pernikahan dapat mempengaruhi cara pandang terhadap diri, lingkungan, maupun masa depannya, juga terhadap kesehatan mental dan fisik.

Terciptanya kepuasan pernikahan dapat meningkatkan kesejahteraan psikologis pada individu (Diener, dalam Utami, 2009; Khan, 2013). Individu yang memiliki kesejahteraan psikologis yang baik cenderung merasakan afek positif dalam hidupnya, seperti bahagia, merasa puas dengan hidup, dan capable (Huppert dalam Rapheal \& Paul, 2014). Adanya berbagai afek positif ini dapat melindungi individu atau meredam rasa cemas yang dirasakan terhadap menopause.

Partisipan dengan pekerjaan sebagai dosen memiliki tingkat kecemasan yang lebih tinggi dibandingkan partisipan dengan partisipan lainnya. Menurut dugaan peneliti, hal ini karena profesi dosen memungkinkan individu untuk berpikir lebih kritis dan memiliki rasa ingin tahu yang tinggi sehingga mendorong mereka lebih banyak mengakses sumber informasi terkait menopause. Berbagai informasi yang diperoleh individu tersebut justru semakin meningkatkan rasa cemas individu.
Pada penelitian ini juga didapatkan juga gambaran pada perempuan menjelang masa menopause, dimana kebanyakan mengalami tingkat kecemasan sedang yakni sebanyak 73 orang atau mayoritas partisipan penelitian ini. Hal ini mengindikasikan partisipan merasakan cemas terhadap menopause namun kecemasan ini belum terlalu intense dan belum mengganggu keberfungsian mereka sehari-hari. Tingkat kecemasan yang berada dalam taraf sedang ini juga mengindikasikan bahwa kemungkinan individu telah melakukan sejumlah upaya untuk mengelola kecemasannya, meskipun belum terlalu efektif. Salah satu upaya yang dapat dilakukan individu adalah dengan melakukan regulasi emosi (Sulistyo, 2014).

Penelitian ini memiliki sejumlah keterbatasan. Pertama, penelitian ini hanya dapat mengetahui hubungan antara variabel yang diteliti, namun tidak dapat diketahui berapa besar sumbangan kepuasan pernikahan untuk kecemasan terhadap menopause. Penelitian selanjutnya dapat diarahkan untuk mencari besar sumbangan tersebut. Kedua, penelitian hanya melibatkan partisipan dari tahap usia dewasa madya (40-48 tahun). Dengan demikian, penelitian ini tidak dapat di generalisir pada perempuan dengan tahap usia dewasa awal atau remaja, baik yang berada di kota Jakarta atau yang berada di daerah lain. Penelitian selanjutnya dapat diarahkan pada populasi dan karakteristik partisipan yang berbeda, misalnya kelompok perempuan berusia remaja, dewasa muda, perempuan yang tinggal di pedesaan, dan sebagainya. Selain itu, mengingat kemungkinan meningkatnya angka harapan hidup maupun gizi, maka usia dimulainya masa menopause pada perempuan bisa berubah-ubah. Peneliti berpendapat, penelitian selanjutnya harus 
lebih cermat terkait hal ini dan menggunakan data terbaru mengenai kapan dimulai menopause pada perempuan Indonesia. Keterbatasan ketiga, pada uji beda yang didapatkan perbedaan yang signifikan antara kecemasan terhadap menopause dengan faktor demografi (agama dan pekerjaan). Meskipun demikian, distribusi sampel pada demografi tersebut tidak merata sehingga perbedaan tersebut mungkin saja muncul bukan karena sisi demografinya namun karena distribusi atau faktor lain. Dalam penelitian ini, belum dilakukan analisis mengenai perbedaan tingkat kecemasan dalam menghadapi menopause berdasarkan gejala yang dialami partisipan. Penelitian selanjutnya diharapkan melakukan analisis terhadap hal tersebut dengan menggunakan paired sample t-test. Kemudian, penelitian selanjutnya dapat menggali faktor-faktor lain, baik yang terkait dengan relasi pernikahan maupun tidak, yang diduga berkorelasi dengan kecemasan terhadap menopause pada perempuan dengan usia menjelang menopause.

\section{SIMPULAN SARAN}

Hasil penelitian ini menunjukkan terdapat hubungan antara kepuasan pernikahan dengan kecemasan terhadap menopause pada individu yang berada dalam tahap usia menjelang menopause. Dengan demikian, salah satu upaya untuk mencegah atau meminimalisir terjadinya kecemasan terhadap menopause adalah dengan meningkatkan kualitas pernikahan pasutri hingga perempuan/istri bisa merasakan tingkat kepuasan pernikahan yang maksimal.

\section{DAFTAR PUSTAKA}

Acevedo, B., Aron, A., Fisher, H., \& Brown, L. (2012). Neural correlates of marital satisfaction and well- being: reward, empathy, and affect. Clinical Neuropsychiatry, 9, 20-31.

Aprilia, N.I \& Puspitasari, N. (2008). Faktor yang mempengaruhi tingkat kecemasan pada wanita perimenopause. The Indonesian Journal of Public Health, 4(1), $35-42$.

Christiani, R. S., \& Purnamaningsih, E.H. (2000). Hubungan persepsi tentang menopause dengan tingkat kecemasan pada wanita yang menghadapi menopause. Jurnal Psikologi, 2, 96-100.

Dehle, C. \& Weiss, R. L. (1998). Sex differences in prospective associations between marital quality and depressed mood. Journal of Marriage and the Family, 60, 10021011.

Depkes. (2005). Terjadinya Pergeseran Umur Menopause. Diunduh dari http://www.itjen. depkes.

Faradilla, P. (2010). Kepuasan pernikahan suami yang memiliki istri berkarir. Diunduh dari http://psikologi. ub. ac. id/wpcontent/uploads/2013/10/JURNA L5.

Fauziah, F \& Widuri, Julianty (2007). Psikologi Abnormal Klinis Dewasa. Jakarta: Universitas Indonesia Press.

Fowers, B., \& Olson, D. (1993). ENRICH marital satisfaction scale: A brief research and clinical tool. Journal of Family Psychology, 7 (2), 176185.

Hanafiah, J. M. (1999). Meningkatkan Kualitas Hidup Wanita Menopause. Majalah Medika, No.1, Th XXV, 33-38.

Handayani, L. L. (2015). Hubungan Perubahan Fisik dengan Kecemasan pada Wanita Menopause di Dusun Gatak 
Bokoharjo, Prambanan, Sleman Yogyakarta. Yogyakarta: Sekolah Tinggi Ilmu Kesehatan Aisyiyah. Diunduh dari http://opac.unisayogya.ac.id/590/ 1/PDF\%20NASKAH\%20PUBLI KASI.pdf.

Hidayah, S.N., Hadi, M., \& Atik, N.S. (2016). Tingkat kecemasan wanita usia 40-45 tahun menghadapi masa pramenopause di desa Tumpang Krasak, kecamatan Jati, kabupaten Kudus. Jurnal Kesehatan dan Kebidanan, 6(1), 54-64.

Prasetya M. R., Firmiana, M.E., \& Rochimah, I. (2012). Peran religiusitas mengatasi kecemasan masa menopause. Jurnal AlAzhar Indonesia Seri Humaniora, 1(3), 145-157.

Levenson, R. W., Carstensen, L. L., \& Gottman, J. M. (1994). Long term marriage : Age, gender, and satisfaction. Psychology and Aging, 8(2), 301-313.

Muharam. (2007). Makalah disampaikan dalam Simposium Nasional Perkumpulan Menopause Indonesia (PERMI), Jakarta 2122 April 2007.

Muntiah \& Ni'amah, S. (2013). Faktorfaktor yang berhubungan dengan kecemasan ibu menghadapi masa menopause di desa Boto, kecamatan Jakenan, kabupaten Pati. Jurnal Ilmu Kebidanan dan Kesehatan, 3(2), 69-74.

Nevid, J.S., Spencer, A., Rathus., \& Greene, B. (2005). Psikologi Abnormal. Terjemahan Tim Psikologi Universitas Indonesia. Edisi Kelima. Jilid 1. Jakarta: Penerbit Erlangga.

Rostiana, T. \& Kurniati, I.M.T. (2009). Kecemasan pada wanita yang menghadapi menopause. Jurnal Psikologi, 3(1), 76-86.

Sumpani, D. (2008). Kepuasan Pernikahan Ditinjau dari Kematangan Pribadi dan Kualitas Komunikasi. Surakarta: Universitas Muhammadiyah Surakarta (Skripsi).

Salehi, F., \& Shahhosseini, Z. (2017). Association between women's marital satisfaction and anxiety during pregnancy. Psychiatric Behav Scie, In Press.

Diunduh doi: $\quad 10.17795 /$ ijpbs-7937.

cdn.neoscriber.org/cdn/dl/952e543ee707-11e6-9e28-6f8230b41146.

Sarason \& Sarason. (2004). Abnormal Psychology: The Problem of Maladaptive Behavior, $9^{\text {th }}$ Edition. New Jersey: Prentice Hall.

Sulistiyo, E. (2014). Hubungan antara Regulasi emosi dengan Kecemasan menghadapi Pertandingan. Diunduh dari http://eprints.ums.ac.id/37466/9/0 2.\%20Naskah\%20Publikasi.pdf.

Sugiyono. (2010). Metode Penelitian Manajemen. Bandung: Alfabeta. 